DIGITAL COMMONS
@ UNIVERSITY OF SOUTH FLORIDA

Journal of African Conflicts and

Peace Studies

January 2021

\title{
Contextualizing the Politics of Ten-Household Cluster Initiatives (Nyumba Kumi) for Human Security in Kenya
}

\author{
Edmond M. Were \\ Kisii University, wearywere@gmail.com \\ Paul A. Opondo \\ Moi UNiversity, opondopaul1@gmail.com
}

Follow this and additional works at: https://digitalcommons.usf.edu/jacaps

Part of the African Studies Commons, Asian Studies Commons, Peace and Conflict Studies Commons, Political Science Commons, Public Administration Commons, and the Terrorism Studies Commons

\author{
Recommended Citation \\ Were, Edmond M. and Opondo, Paul A. (2021) "Contextualizing the Politics of Ten-Household Cluster \\ Initiatives (Nyumba Kumi) for Human Security in Kenya," Journal of African Conflicts and Peace Studies: \\ Vol. 4: Iss. 2, . \\ DOI: https://doi.org/10.5038/2325-484X.4.2.1113 \\ Available at: https://digitalcommons.usf.edu/jacaps/vol4/iss2/2
}

This Article is brought to you for free and open access by the Open Access Journals at Digital Commons @ University of South Florida. It has been accepted for inclusion in Journal of African Conflicts and Peace Studies by an authorized editor of Digital Commons @ University of South Florida. For more information, please contact digitalcommons@usf.edu. 
Contextualizing the Politics of Ten-Household Cluster Initiatives (Nyumba Kumi) for Human Security in Kenya

\section{Cover Page Footnote}

Edmond M. Were is an Associate Professor of Peace and Conflict Studies at Kisii University, Kenya Paul A. Opondo is a Senior Lecturer of History at Moi University, Kenya 


\section{Introduction}

The contextualization of the politics surrounding the adoption of the tenhousehold cluster initiative (Nyumba Kumi) in Kenya as a way of addressing existential threats is located in the experiences initially borne outside the African continent. Whereas the Kenyan initiative is popularly presumed to have been borrowed from Tanzania, its oriental roots are more credible especially with regard to the practice of household registration systems that influenced population mobility, crime prevention, access to basic human needs, social and spatial structure, and extraction of loyalty to the establishment. Some Western European countries have also judiciously practiced the statist population registration system while others resorted to the voluntarist neighborhood watch system. These systems have had a significant influence on the management of state and human security in the respective countries. In this paper, we anchor the initiatives in the political theories of individualism and communitarianism that illuminate on the underpinning power relations.

This paper provides selected global and continental African contexts that illuminate on the politics of adoption and implementation of the Nyumba Kumi initiative in Kenya. The experiences from selected political dispensations and the accompanying political theorizing are primed to cause informed discourse on the viability and sustenance of the ten-household initiative in Kenya. In the African, Oriental and Cuban initiatives it points out that the state is a major actor in their design and implementation hence its rationalization through the theory of communitarianism. The Western world, on its part, has pursued the individualist approach hence the preponderance of Neighborhood Watch groups that are formed from a voluntarist perspective. In both worlds, though the initiatives are grounded at the local levels, their main thrust is that they are the 'ears and eyes' of state security agencies.

Kenya's late entry into the roster of countries implementing the Nyumba Kumi initiative for managing threats has over time been met with resistance, doubts, confusion and ambivalence. This comes at a time when residents' associations have been a preferred strategy for addressing household and community security especially in the context of a general feeling of frustration from the masses about widespread institutional failures. In a rapidly developing country where individualism has taken deeper roots, the Nyumba Kumi initiative has convincingly been linked to socialist and communist political modus operandi, thus becoming seemingly untenable in its current form. The insights generated in

this paper inform the redesign of the Kenyan version in the pursuit of human security. 


\section{Conceptualizing the Ten-Household Cluster}

The ten-household cluster initiative arises from the state's need to profile and characterize the person and his/her behavioral traits in a locality. Since ancient times especially in ancient China, the profiling and characterization of persons involved a civil registration process at the household level for purposes of planning and realization of larger societal goals. In modern times, the conceptualization has been broadened to enable linkage between the state and the masses to realize mainly state security and in rare cases human security. The household cluster is nominally conceived as a unit comprising ten or more households that share aspirations, needs, concerns or fears and are required to address them in partnership with relevant state agencies. In the known cases across the globe they are established in pursuit of specific political, security, administrative and development planning goals. They take different forms and their implementation is a preserve of the state.

Household cluster initiatives have been linked to various modes of political, economic and administrative organization. They evolved from a simple household registration system into a strategy for civic engagement and participation primarily in party and community activities that affirmed social and political citizenship. In Eastern Africa, the ten-household clusters are popularly known as Nyumba Kumi(especially in Kenya, Uganda, Tanzania and Rwanda) and kebele in Ethiopia, Committee for Defense of the Revolution(CDR) in Cuba, hukou or huji in China (Xhao, 2017, Congressional Executive Commission on China, 2005) koseki in Japan (Pollock, 2016) hoju in North and South Korea and propiska in the Soviet Union-Russia (Kessler, 2001). In Russia and the East Asian states, the clusters register household residents, control population movements between rural and urban areas, support the national administrative structure and where appropriate engage in local dispute settlement. These roles have largely been adopted in the Eastern African as well as Cuban initiatives.

Apart from Germany and a few other European states, the North American and the United Kingdom prefer using Neighborhood Watch groupings for community policing and civic engagement which in most cases involves partnership with local policing agencies. The Neighborhood Watch groups are voluntarily formed and managed but establish close working relations with the police making them indispensable in the maintenance of security of person and property. To gain deeper insight into the ten household cluster and the neighborhood watch initiatives we delve into political theory and locate both in the theories of individualism and communitarian as discussed in the next section. 


\section{Theoretical Framework}

Human security has been threatened for millennia and initiatives aimed at sustaining it have also undergone innovative trial and error over time. Since classical times and even before, philosophical and theoretical explanations have attempted to illuminate on the ideal man-society and state-society relationships that would guarantee human security in varied political settings. Explanations from liberal, neo-liberal, realist, neo-realist, constructivist, Marxist or green politics standpoints tend to focus on the pursuit of an apt state-society relationship that assures the good life for man. The argumentations are traced to prominent works by Thucydides, Thomas Hobbes, John Locke, St. Augustine, St. Aquinas, Karl Marx, Lenin, Machiavelli, among many others, whose works provide a peek into political organizing and structuring in the management of man and power relations. In these works, the state emerges as a predominant political agency responsible for both human and national security. In this respect, we discern the pertinent argumentations encapsulated in the History of the Peloponnesian War, Leviathan, Republic, Prince, Social Contract, General Will, Das Kapital, and the Communist Manifesto, among others. From these works, we are able to identify two variants of political theory that highlight the rationale and dynamics of assuring a secure human existence.

In the theory of individualism, the individual is methodically the basic unit of social relations (Kelly, 2011). In this respect, human groupings such as Neighborhood Associations or the Ten Household Clusters (Nyumba Kumi) are explained through actions and choices of individuals who compose them. Individual needs are more crucial to the needs of the wider association. This trend of thought is traced in the works of Thomas Hobbes, as well as John Stuart Mill and Jean Jacques Rousseau. Normatively, the individual stands out as primarily important based on the inherent human rights. As a result, associations emerge to concretize the protection of the inherent rights of individuals. This trend of thought is traced in the works by John Locke and John Stuart Mill. The formation of Neighborhood Association in the Western world is thus informed by this theoretical explanation.

In the theory of communitarianism, the group is methodically the basic unit of social relations. Using Karl Marx and Hegel as sources of explanation, it is postulated that social relations in groups are crucial for individual human security. Normatively, communitarianism presents the position that human beings are what they are because of the relations that they construct in society. Hence, group membership has the first claim on individuality and enhances enjoyment of certain individual rights. The creation of social relations through belonging to 
such groups as Nyumba Kumi, kebele, gott or garee thus presupposes the guarantee of individual rights and responsibilities. In countries where it is a requirement to belong to such groupings, the assumption is that individual security is fostered through participation in the distinct established structures and processes.

To this day and age, the state has remained an omnipotent human organization and in a number of developing countries and developed countries, state security, disguised as national security, has taken precedence in strategic political and economic actions at the expense of human security. In most developing countries, the state has failed to guarantee 'freedom from want' and 'freedom from fear' for the majority of its citizens as "the best path to tackle the problem of global insecurity" (Wikipedia). Those states that prioritized their own security as a precursor to human security later innovatively introduced grassroots-based initiatives that play varied social, economic and political roles. In these political dispensations, the initiatives are perceived to be the 'eyes and ears' of the state. Human rights violations have overtime emerged during their implementation.

It is instructive to appreciate that the household cluster initiative is more appealing initially in predominant single political party developing states professing a more radical, transformative or populist political ideology. Later, it became popular in formerly failed or post-conflict states. The initiatives were considered as paradigm shifts in governance whereby the masses got involved in controlling their destiny. The adoption of the initiatives in emerging pluralist democracies on the African continent is nevertheless cumbersome. It is more problematic in states where the ideology of the ruling party does not represent the political beliefs of sections of the population. In this context, the Kenyan security realm is thus interrogated.

\section{Global Initiatives}

The introduction of the ten-household initiative in Eastern Africa to address security and sociopolitical challenges was largely influenced by similar initiatives in Asia and Europe. It is traced to China during the reign of the Duke of the state of Tsin. McGowan (1897) states, in A History of China: From the Earliest Days to the Present, that the Duke was in need of reforms that would transform his state to greater heights. In circa $362 \mathrm{BC}$, Wei Yang, the witty advisor to the Duke, was mandated to institute administrative and legal reforms which included the introduction of

"(1) the ten house system; (2) in every family where there were two grown up sons one of these should go out and form a new 
household, or else double taxes should be levied; (3) the rich should not be required to do personal service on the public works, but be permitted to compound by a money payment to the state. The poor, however, and especially the indolent, were required to attend with their wives. They would be thus cured of their laziness, and at the same time earn money that would go to the support of their families; (4) every man that travelled through the state must have a passport, and any inn-keeper that lodged strangers without such would be liable to a severe penalty" (McGowan, 1897:72)

The new rules were disliked by the people but stringent enforcement ensured submission. The author argues that "after they had been in force for ten years the whole character of the state was changed, for thieves disappeared from it, the indolent became industrious and a spirit of widespread loyalty was engendered" (p.73).

In the $20^{\text {th }}$ century, China revisited the household registration system, hukou, that was formally implemented a decade after the 1949 Cultural Revolution. This system became instrumental in the country's push for rapid industrialization and stemming rural exodus in efforts to realize socialist development (Chan, 2010). It was a population registration system administered by the Public Security Bureau that required each household member to carry a registration pass (hukou) issued on the basis of residential location (hukou suozaidi) and socio-economic eligibility (hukou leibie). The registration details entail residential address, religion, employment information, birth and death, nationality, native place, educational level, class, status, and military record. The card distinguished between rural and urban dwellers and guaranteed access to prescribed basic services (Chan and Buckingham, 2008).

The hukou system was a key part of the command economy and central planning and was instrumental in the creation of dual classification of the Chinese population into rural and urban dwellers, restricted the movement of rural dwellers to towns and strictly enforced restrictions on transfer of socio-economic status from rural to urban including claiming residence in urban areas by rural hukou holders" (Chan and Buckingham, 2008). Nevertheless, its implementation has been severally criticized for dehumanizing and discriminating against the rural population.

The Chinese hukou system draws inspiration from propiska - the internal migration regulations system instituted in the Soviet Union in 1932 (Hatcher and Thieme, 2016). Propiska was a "compulsory territorial registration of the 
population in which every person was registered at a particular address. In accordance with registered residency, he/she got access to employment, primary and secondary education, healthcare, and other social benefits" (Ivakhnyuk, 2009). Like in China, internal migration policy has been shaped in accordance with state interests and monitored from the perspective of the state. This is done with national security at the top of priorities. Propiska allowed local and city authorities to monitor population migration and residence and was enforced through residency restrictions which required deregistration and registration on taking new residence. New registration was to be done within 90 days of movement (Immigration and Refugee Board Canada, 2009). The registration stamp provides the time period that one would reside in a specific region. In addition, it authorized the holder to work in a particular town and reside at a specified address. The successive regimes since Stalin were able to "tie collective farm workers and other rural dwellers to the land and restrict mass migration to cities" (Hatcher and Thieme, 2016: 2180). It later evolved into an "instrument of repression and police control and, in the short run, more crudely as a purging tool as kulaks and other individuals that fell outside the socialist ideal were cleansed from cities and other regime areas" ((Hatcher and Thieme, 2016: 2180). In larger cities, it allowed the authorities to "expel people from the city who 'avoided socially useful work', whose behavior was 'unworthy', and who 'infringed the rules of the socialist community" ((Hatcher and Thieme, 2016: 2181)). Since the advent of perestroika, emigration restrictions have been reformed though the residence restrictions still persist.

The closest equivalent to the foregoing Asian initiatives is the Neighborhood Watch system that is practiced in some European countries, USA and emerging economies in East Asia. It is attributed to the contested understanding that crime reporting and reduction are intimately related (Bennet, Holloway and Farrington, 2009). It is traced to the United States of America in the 1960s at the height of urban crime and it is recognized to be effective in impacting on the perceptions and decision making of potential offenders through "watching and reporting" (Bennet, Holloway and Farrington, 2009:4). Neighborhood Watch Groups were eventually incorporated into community policing initiatives and integrated in counterterrorism strategies through the National Sheriffs Association (NSA) and USAonWatch. The watch groups comprise "people living in the same area who want to make their neighborhood safer by working together and in conjunction with local law enforcement to reduce crime and improve their quality of life" (US Department of Justice, 2005: 1-37). Since 1972 the National Neighborhood Watch evolved into a partnership between citizens and law enforcement and later engagement in disaster preparedness and emergency response. 
Just like in the USA, Neighborhood Watch groups have been ubiquitous in the United Kingdom as ears and eyes of the police since 1982. They also evolved into agencies that address the general concerns of quality life in the neighborhoods including street sanitation, broken and dripping pipes and community parks (US Department of Justice, 2005:11). This is similarly practiced in Singapore through the Neighborhood Watch Zone (NWZ) scheme. The Singaporean scheme focuses on cultivating synergy between the police and resident committees and associations. It encourages neighborhood residents to "take personal responsibility both individually and in partnership with others in safeguarding themselves, their property and their neighborhood with the advice and assistance of the police" (Singh, n.d). It also addresses 'all issues that interest and affect the community and "coordinates crime prevention activities and programs to foster community bonding" and further disseminate information to residents and provide feedback to the police.

The Neighborhood Watch concept informs the thinking and adoption of similar initiatives elsewhere especially with regard to integrating human security into the daily livelihood agenda of communities. They are more inclusive, voluntarist and tend to portray a democratic policing character. The initiatives are slowly emerging in the urban settings in developing countries. They, however, assume a vigilante form in poorer neighborhoods but get more organized as neighborhood associations in wealthier neighborhoods.

Outside the American and European realms, neighborhood watch initiatives are designed by the state primarily to perform political mobilization and territorial administrative roles. This is more evident in Cuba where the Committee for the Defense of the Revolution (CDR), being part of the party and state bureaucratic system, was conceived as the "foundation of Cuba's democratic superstructure, where people participate directly in resolving their problems" (Kruger, 2007). Just like the Chinese, Soviet, American and UK systems, the CDRs are the "eyes and ears' of the Cuban Revolution, with a responsibility of promoting social welfare and reporting on counter-revolutionary activity. They were established "so that everybody knows who lives on every block, what they do on every block, what relations they have had with the tyranny, in what activities are they involved, and with whom they meet" (Sanchez, 2012). They were thus considered "a collective system of revolutionary vigilance." By 2010, more than two-thirds of Cuba's national population belonged to the $\mathrm{CDR}$.

The hierarchical structure of the CDR extends to the whole country and the neighborhood members perform various roles including vigilance, public health, youth, finances, recycling and voluntary work, member familiarization, and 
general neighborhood sanitation activities (Kruger, 2007:108). The CDR activities have been criticized and compared to the 1930s Hitler era "Committees of Territorial Vigilance" that were the ears and eyes of the Nazi regime. The CDR has particularly been accused of human rights infringement in the country (Veltmeyer and Rushton, 2011).

Western Europe has, nevertheless, also implemented population registration systems similar to the Asian initiatives. For instance, the German Police Registration System is geared at tight control of all the inhabitants living and residing in the country. The local police departments are agents of the registration department and keep record cards on citizen and alien persons, buildings and human resources. The system acquired notoriety during the Third Reich. Registration cards were copied to Nazi Party headquarters for purposes of mobilization and political recruitment. Specialized registration systems were also maintained at the Gestapo (secret police) offices where people were categorized according to degrees of danger to the state and race. The registration system has been a tool of control which "ensures follow up of each person's family status, movements, activities and occupation" (Kempner, 1946). The system was largely inherited in Post-war Germany. To-date, the Anmeldungsamt (registration bureau) ensures registration of citizen and non-citizen residents within specified periods and at particular residences. The registration process yields "invaluable information on inhabitants of a given district, means of identification, number of males and females, persons belonging to a certain age, class, profession, occupation, religion, exact address etc." (Kempner, 1946):362). The information is available for use by state agencies such as the law enforcement officers, urban planners, demographers, etc. The system ensures continuous registration of all inhabitants at the local levels and is usually revised to ensure it is up to date (Kempner, 1946):365).

The above information compares starkly with the practice of the household cluster system on the African continent. We selected a few countries on the continent that have implemented the system largely for guaranteeing their state and communal security. The practices vary in intent and

\section{Continental African Initiatives}

The African continent is home to a myriad of traditional cultural agencies that were mandated to regulate village life by ensuring the community's wellbeing. Livelihood revolved around structures and processes established by tradition and custom. Their effect was thus largely felt and limited to the local village level (Vogt, 1917). Unlike the ancient Chinese initiative of 'ten houses,' the African 
villages as composites of households lacked direct structural linkage to superstructures beyond the clan. Their capture into the national superstructure is resultantly a fundamental process of change in the lives and orientation of villagers (World Bank, 2006). At the village level, one encountered cultural agencies comprising the youth and community elders whose prime role was to ensure safety, stability and security of their respective communities. Various communities on the African continent attest to the existence of institutions such as the morans and councils of elders that engaged in ensuring the wellbeing of their communities. In more traditional African societies, like the Acholi, Luo, Dinka, Maasai, Meru, Kikuyu, Pokot or Somali, some of these agencies still exist. Modernity has, however, seen the gradual erosion of their roles and to all intents and purposes being left in the shadows of the national security discourse (Makinda, 2006). Their negligence and marginalization could as well explain the sprouting of deviant groups in several African communities that challenge not only the authority of the state but also security of their communities.

A number of African countries later transformed the village structures into household cluster initiatives that were part and parcel of the national administrative structure. The intention was partly to engage grassroots populations in the maintenance of security at the local level within the context of the state. This emerged as a reaction to the existing insecurity phenomenon that posed challenges to mainstream national security. It was further challenged by the fact that most African countries are plagued by the reality of swathes of ungovernable regions arising from the virtual absence of state machinery. In postconflict states, a couple of years after their independence, the need for 'democratic policing,' that is the voluntarist involvement of the populace in individual and communal security, came to be regarded as a progressive approach to building a more stable polity. Later years saw the initiatives transform into mechanisms for mobilizing the populace to participate in community development activities such as public health and sanitation in their neighborhoods.

The modernization and change processes have introduced more social challenges which have necessitated a number of African countries to establish complementary grassroots political and administrative structures to address state scarcity in the expansive rural areas. These structures are presumed to fulfill both political and bureaucratic roles at the local levels. In an increasing number of cases, they owe their establishment to ideological influences from left leaning or authoritarian regimes in Europe, Asia and the Caribbean. It is instructive to note that the ten-household cluster initiative on the continent is generally preferred in political dispensations that do not wholly subscribe to nominal democratic values 
(Cook, 2004; Treiber, n.d; Sima, 2017). It has been instrumental in ensuring the sustenance of the political status-quo and popular mobilization in support of ideological preferences of the ruling class. Being the grassroots-based administrative and security unit, it is a key agency in ensuring popular acquiescence or facilitation of repressive tendencies in those states experiencing opposition to the political establishment. It is thus paradoxical that the initiative that nominally rests on the aspirations of popular participation and community engagement in democratic policing has exhibited anti-democratic credentials as highlighted in the following selected cases.

The current Ethiopian governance structure is an elaborate and well-organized nationwide political and administrative system that came to be since the overthrow of the Haile Selassie monarchy. The post-monarchy Derg structured the country's population into household groups known as kebele. The kebele were, initially, responsible for implementing the state's rural development agenda and land reform which later evolved into a highly effective mechanism for control and repression (Human Rights Watch, 2005). The kebele were involved into 'perpetual surveillance' in the community, reported on subversive elements in the society, and most importantly disseminated government propaganda, implemented state policies and kept order and discipline. The post Derg-regime has continued using the kebele system to cause social change in the rural areas and consolidate the powers of the ruling party across the country. In the Oromia region of Ethiopia, the kebele were further restructured into smaller household groups, the gott and garee which are instrumental in exercising judicial roles at the local level. They are supervised by the Bureau of Mass Mobilization, Culture, Sports and Social Affairs at the regional level and ensure that 'work' is done. Their activities have variously been criticized for human rights infringements (Human Rights Watch, 2005: 3-5).

The Tanzanian ten-household initiative is even more controversially elaborate. The initiative known as Nyumba Kumi was a brainchild of the then ruling party, the Tanganyika African National Union (TANU). It was supposedly borrowed from Maoist China, introduced to Dar-es-Salaam in 1964 and later to the rest of the country (Cross, 2014). It was a subunit of the ruling party which later became part of the village administrative structure (Ingle, 1972). The initiative later became an effective strategy for political mobilization and sensitization for the party socialist ideology since 1964. Each Nyumba Kumi cell was led by a balozi who enabled expression of popular "views and opinions to TANU and government and to communicate the policies of TANU and government to the people, consolidate unity and extend leadership to the village level so that leaders can easily be accessible to the ordinary people, obtain information regarding 
social and economic development in the villages and forward it to the branch organs of TANU and ensure the security and survival of the Party, Government and the nation by seeing ... that all laws and regulations are obeyed" (Ingle, 1972: 215). In international border areas, the leader would essentially be part of the "security system, informing on all unusual people or happenings in the area" (Ingle, 1972:216).

The 1967 Arusha Declaration affirming the Ujamaa (Socialism) ideology and launching the Chama Cha Mapinduzi party energized the role of the cell leader as a doyen of rural development, work, political mobilization and unity in the nation. The advent of multiparty politics, however, saw the waning influence of the Nyumba Kumi system and institutionalization of community policing (polisi jamii) by 2006 (Cross, 2014). Nyumba Kumi thus precedes Community Policing, which has been hailed for its ability to fight crime though it is more of top-down than a community-based initiative. Community policing is further linked to the Sungusungu initiative - an organized state-led vigilantism that partners with the local police in the provision of security and performance of local juridical responsibilities (Fleischer, 2000). A Peoples Militia Act was passed to regularize and recognize the Sungusungu vigilantism. Such recognition made "participation in neighborhood patrols mandatory for all able-bodied males between the ages of 18 and 60 in rural and urban areas" (Fleischer, 2000). The militia's activities were monitored by party and Nyumba Kumi leaders. The partnership established ulinzi shirikishi (security partnership) that ensured security partnership at the grassroots level and which borrows a lot from the vigilantism that came to the fore in the 1980s and 1990s. It, however, led to accusations about human rights violations due to the modalities used in extraction of information from suspects.

The Ugandan Mayumba Kumi initiative mirrors the Tanzanian Nyumba Kumi case. It was first established by the Second Obote regime (1980-85) ostensibly to monitor the insecurity occasioned by the National Resistance Movement (NRM) rebel activities. It later evolved into $a$ "system of administration (more so security system) which would cluster ten houses to ensure people know who is who in a locality. It ... aimed at improving vigilance, security awareness among other things" (Ndyabahika, 2017). The NRM rebel movement also adopted it in the internment camps during the five year struggle against the Obote regime essentially for reeducation of the masses on the Ten-Point program (Bymes, 1990). The program agenda facilitated a paradigm shift in diagnosing and resolving the endemic problems that befell Uganda since independence. The Mayumba Kumi later became the lowest security tier of the state hierarchy (Jones, 2005). The establishment of elected local councils replaced the Mayumba Kumi as 
agents of community policing since 2013. Spikes in insecurity in the country later led to the introduction of the Crime Preventers initiative to provide a link between the Uganda Police Force and Ugandan communities in the fight against crime. In between, the country also implemented the Chakamchaka Political Education program as a civic education program aimed at bureaucrats, politicians and selected sections of the population. Virtually all these initiatives have been criticized for flagrant violation of human rights arising from their highhandedness (Ssemakula and Mohmeded, 2017).

Post-Genocide Rwanda was faced with a myriad of problems, one of which was the resettlement of returnees. The state embarked on the deliberate reorganization of the resident and returning population into villages (imidugudu) from which they could easily access government services. "The Cabinet Decision stated that the dispersed settlement pattern in the countryside was a waste of space, and, therefore, all the rural inhabitants should be regrouped in villages (imidugudu)" as a way of ending settlement spontaneity and introduction of spatial planning for habitation, agriculture and grazing (Hilhorst and Leeuwen, 1999). It was basically a reincarnation of the Tanzanian villagization program albeit without the ideological mantra. The resettlement program was later integrated into maintenance of communal security that was institutionalized into the Nyumba Kumi initiative. It became the lowest echelon of local administration and headed by a Nyumba Kumi head, simply known as Nyumba Kumi (USAID-Rwanda, 2008). After the 2006, the Nyumba Kumi heads were replaced by the newly elected imidugudu leaders. To-date the imidugudu heads enforce state directives including knowledge of all residents and visitors in the village, resolving household disputes, mobilizing local residents for the monthly umuganda (obligatory community work), attending gacaca courts when they were in operation, and volunteering for the irondo ry'umwuga (community night patrols). Their roles have contributed to the relative safety, security and public sanitation that Rwanda is now renowned for (Rwanda National Police, 2016). The Nyumba Kumi/imidugudu initiatives in Rwanda have, however, been criticized for being unrelenting political and security apparatuses of the state at the local level and gradually becoming socially and financially burdensome to the residents (Sabiti, 2017).

The foregoing analysis of the array of global and continental initiatives establishes the context in which the Kenyan Nyumba Kumi initiative can be comprehended with regard to the underlying ideology, practice and emerging challenges. It is apparent that the running thread in the African initiatives are complaints of human rights infringements, though their role in maintaining law and order is discernible. Their preoccupation with state security concerns has 
overshadowed and minimized their involvement in human security initiatives. Their popular legitimacy is thus increasingly being challenged. In the next section we present the politics of Kenya's Nyumba Kumi scenario as an attempt to address the challenges of insecurity. We argue that the current rationalization of the initiative is narrow and basically faulty in its design and implemenation. Nevertheless, the initiative has potential to impact on the lives of citizens if the conceptualization, design and implementation were broadened to embrace human security attributes.

\section{Nyumba Kumi Initiative and Neighborhood Associations in Kenya}

National security in Kenya has for long been perceived through neorealist lenses in which security of the state assumes precedence over human security. Such perception has limited the strategic latitude with which policy makers would design appropriate interventions into existential threats. In its 2010-2014 Occasional Report, the Kenya National Commission on Human Rights (2014) acknowledges the level of lawlessness and insecurity in the country. There is a proliferation of criminal gangs in every county even as the capacity of the policing agencies dwindles. This has provided a leeway for the more daring organizations like Al Shabaab, Baghdad Boys, Chinkororo, and Sabaot Land Defense Force etc. to escalate their recruitment forays as well as cause harm to the lives of the citizens (Cannon and Pkalya, 2017).

The state has, nevertheless, approached the security challenge from a narrow prescriptive, reactionary and coercive perspective. The directive for the introduction of the Nyumba Kumi initiative in 2013 was rationalized from such a standpoint. "The government has ordered the implementation of "Nyumba Kumi" (ten houses) community policing concept in an effort to enhance security in villages. Interior Cabinet Secretary ... told security chiefs in Nairobi to ensure the current system of villages under a village elder were restructured into ten household units, with a clear leadership structure that will be responsible for the security of the concerned households" (Ombati, 2013). He argued that the "concept has been tried in Tanzania with positive impact in terms of improved security." This directive was reactive and lacked an ideological backup that would have endeared it to the population and the implementers. It was delivered without the demagoguery necessary in appealing to the emotions of the population especially at that particular time when patriotism was challenged by terrorism. Furthermore, the Tanzanian connection ignited immediate doubt and suspicion about its efficacy and acceptability in the pseudo-capitalist context that reins in the Kenyan society. 
A reconceptualization of security and the attendant security infrastructure that fits into the securitization and widening paradigm of the Copenhagen School of thought and human security approach of the United Nations Development Program (UNDP) is needed (McDonald, 2008). At stake is the incorporation into the security narrative of the seven UNDP human security elements, that is, economic, food, health, environmental, personal, community and political security (United Nations Development Program, 1994). Within this conceptualization, Kenya emerges as a very insecure polity that persistently suffers from threats engendered by structural inequity and inequality, intra and interstate terrorism, insufficient food supplies, ill-health, unsanitary public environments, prevalence of violence and crime, family disintegration, and a pervasive disregard of basic human rights. These threats require sustained and comprehensive responses through informed interventions.

Though Kenya is a late entrant in the realm of community focused security initiatives, the formation of Neighborhood Associations is not new. Most of the Neighborhood Associations are welfare groups that are voluntarily formed to address household needs including neighborhood security and garbage collection. Their emergence has been attributed mainly to 'frustration, in the feeling of dissatisfaction and the no likely sign of these wants being fulfilled under the existing circumstances" (Olima, n.d). This cuts across poor and wealthy urban neighborhoods. Since the onset of the 2010 Constitution, a number of County Governments have formalized these Associations by establishing a legal framework to mainstream their activities and service delivery (Republic of Kenya, 2016). A number of these Associations are single purpose entities which cumulatively have had substantial impact on the livelihoods of residents of rural and urban areas localities (Ndungu, 2016).

Despite the effectiveness and democratic practices displayed by the Neighborhood Associations, the state opted to introduce its version of the Nyumba Kumi initiative without adequate contextualization. The Associations were sidelined in the agenda setting and policy-formulation process. More critical of the rushed 2013 state directive were the Kenya Security Workers Union and Kenya Alliance of Residents Association that felt that the Nyumba Kumi initiative had hijacked their security and surveillance roles at neighborhood level and the state and the public did not adequately comprehend its long-term role (Gumbihi, 2014). However, the state justified the initiative as way of encouraging the exchange of information between residents and security agencies. Being introduced in the wake of the Westgate terrorist bombing, the state generally lamented that "some people with knowledge of suspects were not coming forth for fear of victimization or for thinking security was the obligation of the 
government" (Daily Nation, 2015). It was thus decided to structure the population into ten household units to "say what you see, hear or suspect in a structured manner" and basically cultivate security consciousness at the individual and household level (Daily Nation, 2015). A taskforce was formed to bring the idea into fruition (Republic of Kenya (a), 2013). The state was of the view that the initiative would "create a rapport between citizens and law enforcers in fighting insecurity. It was hinged on the premise that citizens know their areas well and are, therefore, able to spot any suspicious or unusual activities which they then report to the police. Families living in the same area cluster themselves into groups, of usually ten households, with a view to knowing each other better and sharing information among themselves" (Koigi, 2016).

The state linked the Nyumba Kumi initiative to Community Policing and in its 2015 Guidelines on Community Policing, it considered Nyumba Kumi to be "a strategy of anchoring community policing at the household level" (Republic of Kenya (a), 2013). With the establishment of 210,000 clusters, a year later, it was convinced that the initiative would be instrumental in the "elimination of fear of crime and social disorder through joint problem solving; and prevention of crime." This line of argument was pursued notwithstanding the reality that the implementation of community policing was a preserve of the Kenya Police Service whose mandate was to establish "active and equal partnership between the Police and the public through which crime and community safety issues can jointly be discussed and solutions determined and implemented" (Kenya Police Service, 2018). In more affluent neighborhoods, the point of entry was the wellestablished Neighborhood Associations and where these lacked, ad hoc measures were adopted with the help of the local administration.

The Nyumba Kumi initiative was expressly incorporated into the community policing structures, that is, Community Policing Committees and Community Policing Forums. These structures consist of "local leaders, residents, and community based organizations who meet to identify and solve problems in their area" (Kenya Police Service, 2018). The procedure for composition of the forum is not stipulated. It is, however, apparent that membership is by selection rather than election hence defeating their democratic aspirations. The state expressly envisaged Nyumba Kumi to be an appendage of the Kenya Police Service with the goal of facilitating the realization of safer communities. This is rationalized by referring to the initiative as usalama kwa wote and usalama wa msingi that would paradoxically be realized through democratic policing and openness and joint solution to community problems (Republic of Kenya (a), 2013). 
Though the Nyumba Kumi initiative is integrated into community policing it is expected to delve into non-security related issues such as the "felt needs of the clusters" and "giving special attention to vulnerable groups ... resolving conflicts between and within communities through dialogue and to enhance peace and stability" (Republic of Kenya (a), 2013:3). Despite the state denial that Nyumba Kumi is a surveillance mechanism at the local level, it has mandated the initiative to devise methods to promote jua jirani yako (know your neighbor), develop ways to improve the security environment, identify aliens, hotel patrons, tenants, and monitoring social development activities in the cluster area. The initiative is also expected to maps local crime areas and day to day security actions. It further engages in assuring community health needs and wellbeing, managing jigger and other vector infestations, monitoring abuse of drugs and alcohol, monitoring poaching of endangered animals and the general safety of forests in the locality.

Inter-Nyumba Kumi relations are expected to create "an enabling environment for government policing agencies, encouraging greater social contacts and development between neighbors, and creating a gender sensitive environment for greater participation" (Republic of Kenya (a), 2013:3). Due emphasis is placed on Community Policing Clusters in the initiative thus essentially securitizing the pursuit of livelihoods and interpersonal relations at the community level. By 2015, the country had registered over 200,000 Nyumba Clusters that were primarily engaged in security matters (Muraya, 2015). In 2016, the implementation of the initiative was reported to have succeeded in a number of counties with the National Chairman stating that it had reduced crime by $40 \%$ in areas where it has been implemented (Koigi, 2016). Over half of the Counties had embraced the initiative and experienced a "reduction in crime following sensitization of the public," especially in the rural areas (Muhindi and Kinyanjui, 2017).

In 2016, Kisumu County with 4,065 Nyumba Kumi clusters had boosted the fight against insecurity especially cattle theft in a few months. This was attributed to the link between security agencies and the public as a way of building public trust. It was, however, noted that challenges exist arising from a general "lack collaboration between police, chiefs and members of the public whose trust continues to wane" (Ouma, 2016). In Nakuru, the initiative was deemed to be effective in securing communities though it scored low on the social integration scale especially in cosmopolitan communities (Andhoga and Mavole, 2017). It is noted that the initiative has been preoccupied with security issues since inception. Its implementation scope has not been widened to encompass non-security issues that challenge the daily livelihoods of the populace. 
However, implementation intricacies have further been felt by the implementing agency. It specifically identified resistance from "people who are against the idea and our aim is to ensure every resident embrace the initiative" ((Muhindi and Kinyanjui, 2017; Munyao, 2018). It singled out Nairobi City and other major towns where the initiative is "experiencing challenges because police and other government agencies are slow in embracing it. He accused the public of noncooperation" and the "misguided perception among the public in towns that security is the responsibility of the security agencies and not the citizens." In addition, blame was pointed at sectoral rivalries being crucial for the slow acceptance of the initiative.

There are nevertheless expansive areas in Kenya that have experienced incessant insecurity despite the spirited efforts to actualize the Nyumba initiative in all Counties. Other than the urban areas where resistance is established the initiative seems to be ineffective in sparsely populated Counties such as Mandera, Garissa, Lamu, Samburu and border zones between Baringo, West Pokot, Elgeyo Marakwet and Turkana have experienced protracted insecurity to the extent that the Nyumba Kumi initiative is deemed to be inefficient, ineffective or nonexistent. In Lamu, Mandera and Garissa, the Al Shabaab insurgents infiltrate the villages and terrorize the residents amidst heightened state vigilance. In the North Rift Counties, there is untold suffering of the residents leading to huge loss of lives and property arising from cattle theft and rampant ownership of illicit small arms (Kumssa, Jonnes and Williams, 2009). In all these regions, the viability and effectiveness of Nyumba Kumi as a grassroots agency has not been assessed.

At the design stage, there exists muted misconceptualization of Nyumba Kumi, especially among the bureaucrats (Gumbihi, 2014). It is presumed to have been adopted from Tanzania and the ideological basis and motivating factors for its establishment in Kenya are diametrically opposed. Whereas in Tanzania, it preceded community policing and later became unviable as an instrument of security assurance, in Kenya it has been adopted as an integral part of community policing. Seamless implementation of the initiative in Kenya without its contextualization, especially in committing ideological and demagogical resources cannot be guaranteed. Commentators at the Center for Policy Analysis dismissively argued that

"though the government can use various tactics to keep law and order, such methods must be relevant and well understood. [It is] described as a foreign ideology borrowed from a socialist state, it is not likely to succeed in Kenya where many people, especially the urbanites, value their freedoms and privacy. In a society like Kenya, I don't know if it will work, maybe in rural areas where 
people know each other unlike in towns where people prefer privacy. It is not going to be easy to implement it" (Machuki, 2012).

The South African Institute of Security Studies similarly misconstrued it as "simply a community policing (polisi jamii) initiative borrowed from Tanzania and is a strong module for citizen participation in the provision of security. In its ideal form, it helps citizens take ownership of security around them both through conscious tracking of threats in their neighborhoods and through their willingness to tip off security agencies to take appropriate action" (Atta-Asamoah, 2015). Nevertheless, the state sees its role in broader perspectives including policing, juridical as well as other non-security roles at the local level on a voluntary basis, yet, it is a creation of the state having been established as a result basically of institutional failure (Wambui, 2013; Kariuki, 2014).

It is clear that the initiative has recorded successes in rural areas except those of the arid and semi arid North, that are sparsely populated. Urban areas are as well problematic especially with regard to levels of acceptance and participation. The initiative requires a differentiated implementation approach since 'one size cannot fit all.' In the following section we provide pertinent conclusions and recommendations towards the rethinking of the viability and sustenance of the initiative in Kenya.

\section{Conclusions and Recommendations}

The Nyumba Kumi initiative requires a rethink that would inform its redesign. From a human security perspective, the initiative should be anchored in the community rather than the Kenya Police Service structures. Community residents should own the initiative and play a leading role in its leadership and addressing the peculiar security issues that confront them. Public participation and ownership will lead to popular endearment to the initiative. It is then that the people would approach the state for the sought after partnership. The integration of Neighborhood Associations is a reliable entry point in establishing legitimacy at the neighborhood level since they are voluntarily formed and managed.

The status quo in Kenyan communities depicts an imbalance between the people and the state in that the state owns the process of conception and implementation of the Nyumba Kumi initiative. Its anchorage in the community and the birth of the partnership will then require a comprehensive household registration process akin to the German population registration system. Such hybridization will modernize operations of the initiative and further endear it to the people. This will forestall the rampant practice of unmonitored population movements and 
residence in rural and urban neighborhoods that have been a factor in the spread of insecurity.

For Nyumba Kumi to be the 'ears and eyes' of the state there must be a structured process of baseline data collection and analysis as well as gathering of emerging intelligence from the household level upwards. This would be practical in partnership with either the policing or population registration agency. The adaptation of the initiative to the German Anmeldungsamt model will requires all citizens and non-citizens to register at the nearest registration station upon taking up residence. The collected baseline data, on residence, profession, housing, or education will help in planning for community population growth, migration and provision of basic services. Such a system would thus serve not only security concerns but also other national social, economic and environmental needs.

Lastly, sustainability of the Nyumba Kumi initiative in Kenya requires a demagogical backup that would invigorate engagement in common community pursuits like security, public sanitation, etc. This will involve appeal to people's instincts, emotions, and fears that would catalyze popular acceptability. This is the missing gap between the Tanzanian and Kenyan versions. Tanzania popularized its version through simple but strong messaging from the charismatic leadership of TANU and CCM. The people saw hope in being part and parcel of the Ujamaa experiments and took interest in participating in the Nyumba Kumi programs. The Kenyan scenario is bereft of an ideological accompaniment. In fact, the dominant capitalist traits have been used as counter arguments against the initiative. Repackaging and popularization of Nyumba Kumi should be undertaken by populist leaders and not bureaucrats. A populist message should be developed that would philosophically be packaged to guide community actions. This will engender the voluntary spirit that is missing in the initiative.

\section{References}

Andhoga, Walter O., and Mavole, Johnson N., Influence of Nyumba Kumi Community Policing Initiative on Social Cohesion among Cosmopolitan Sub Locations in Nakuru County. International Journal of Social and Development Concerns, (2017) 65-76.

Atta-Asamoah, Andrews, Responses to insecurity in Kenya Too much, Too Little, Too Late? East Africa Report Issue 3, April (2015) 1-17

Bennett, Trevor; Holloway, Katy and Farrington, David, The Effectiveness of Neighborhood Watch (2008) 1-51. See also A Review of the Effectiveness 
of Neighborhood Watch, April 2009, Security Journal 22(2):143-155 DOI10.1057/palgrave.sj.8350076.

Byrnes, M. Rita (ed). "The Ten Point Program." Uganda: A Country Study. Washington: GPO for the Library of Congress (1990), Accessed on 24th January 2018, http://countrystudies.us/uganda/54.htm.

Cannon, J., Brendon \& Pkalya, Dominic Ruto Why al-Shabaab Attacks Kenya: Questioning the Narrative Paradigm, Terrorism and Political Violence, 2017, accessed 24 ${ }^{\text {th }}$ August 2018, DOI:10.1080/09546553.2017.1290607

Chan, K. Wing and Buckingham, Will, Is China Abolishing the Hukou System? The China Quarterly, (2008) 582-606., doi:10.1017/S0305741008000787.

Chan, K. Wing, The Household Registration System and Migrant Labor in China: Notes on a Debate. Population and Development review 36 (2) : (June 2010) $357-369$.

Congressional-Executive Commission On China, China's Household Registration System: Sustained Reform Needed to Protect China's Rural Migrants, (2005) 1-14, accessed 25 ${ }^{\text {th }}$ August 2018, https://www.cecc.gov/sites/chinacommission.house.gov/files/CECC\%20S pecial\%20Topic\%20Paper\%20 ...pdf

Cook, E. Susan, Genocide in Cambodia and Rwanda: New Perspectives, New Brunswick and London: Transaction Publishers

Cross, Charlotte, Community policing and the politics of local development in Tanzania, School of Social Sciences, University of Northampton, United Kingdom (2014) 1-39.

Daily Nation, Nkaissery extends Nyumba Kumi team's term", November 2015. Accessed $2^{\text {nd }}$ November 2017, https://www.nation.co.ke/news/Nkaisseryextends-Nyumba-Kumi-team-tenure/1056-3005466-gb2fl3z/index.html

Fleisher, Michael, Sungusungu: State-sponsored village Vigilante Groups among the Kuria of Tanzania. Africa: Journal of the International African Institute, Vol.70, No.2 (2000) .209-228.

Goldbeg, David, AMISOM Police Launch 'Nyumba Kumi'-Like Community Policing in Kismayo, 2016, accessed 25 $5^{\text {th }}$ August 2018, https://intelligencebriefs.com/amisom-police-launch-nyumba-kumi-likecommunity-policing-in-kismayo/ .

Gumbihi, Hudson, Policing chaos: Kenyans struggle to understand Nyumba Kumi, 2014, The Standard, accessed $7^{\text {th }}$ May 2018. https://www.sde.co.ke/thenairobian/article/2000114571/policing-chaoskenyans-struggle-to-understand-nyumba-kumi

Hatcher, Craig and Thieme, Susan, Institutional transition: Internal migration, the Propiska, and Post-Socialist Urban Change in Bishkek, Kyrgyzstan. Urban Studies (2016), Vol. 53(10) 2175-2191. 
Hilhorst, Dorothea and Leeuven, Mathis van, Women and Vulnerable Groups in Land Dispute Management: A Plan to Ensure That They Fully Participate And Benefit Final Report (2008) 1-13.

Hilhorst, Dorothea and Leeuwen, Mathijs van, Imidugudu, Villagization in Rwanda A Case of Emergency Development? Disaster Sites, no 2, (1999) Wageningen Disaster Studies, pp. 1-50.

Human Rights Watch, Mechanisms Used by the Ethiopian Government to Control Rural Communities in Oromia, (2005) 1-7. Accessed on $12^{\text {th }}$ January 2018. https://.hrw.or/reports/2005/ethiopia0505/6.htm.

Immigration and Refugee Board Canada, China: reforms of the household registration system (hukou) (1998-2004), 2005, Accessed on $10^{\text {th }}$ may 2018. http://www.refworld.org/pdfid/4305fbc04.pdf.

Ingle, Clyde, The Ten House Cell System in Tanzania: Consideration of an Emerging Village Institution, JSTOR (1972) 211-226.

Ivakhnyuk, Irina, The Russian Migration Policy and its Impact on Human Development: The Historical Perspective. Human Development Research Paper 2009/14.

Jones, Benjamin, Local-level Politics in Uganda: Institutional Landscapes at the Margins of the State. London School of Economics. PhD Thesis (2005) $19-25$

Kariuki, James, "Nyumba Kumi the surest way to enhance security in Kenya," 2014, accessed 20 ${ }^{\text {th }}$ August https://www.nation.co.ke/counties/nakuru/Joseph-Kaguthi-NyumbaKumi/1183314-2495060-156vqswz/index.html

Kelly, R., Introduction to Modern Political Thought, 2011, London: University of London

Kempner, M. W. Robert, German National Registration System As Means of Police Control of Population, Journal of Criminal Law and Criminology, Volume 36, Issue 5 Article 7 (1946) 362-387.

Kenya National Commission On Human Rights, Are We Under Siege? The State Of Security In Kenya. An Occasional Report (2010 - 2014), Nairobi: Kenya National Commission on Human Rights.

Kenya Police Service. accessed on $4^{\text {th }}$ May 2018. http://www.kenyapolice.go.ke/pages/links/27-about-us/69-communitypolicing.html.

Kessler G., The Passport System And State Control Over Population Flows in The Soviet Union, 1932-1940, Cahiers Du Monde Russe 2001/2-3-4, Vol 42, 477-504.

Koigi, Bob, Taming Crime and Terrorism, 2016. Accessed on $7^{\text {th }}$ May 2018. https://www.fairplanet.org/story/how-kenyas-ten-houses-concept-istaming-crime-and-terrorism/ 
Kruger, H. Mark, Community-Based Crime Control in Cuba, Contemporary Justice Review, (2007) 10:1, 101-114, DOI: 10.1080/10282580601157919

Kumssa, Asfaw; Jonnes, F. John, and Williams, James, H., Conflict and human security in the North Rift and North Eastern Kenya, International Journal of Social Economics Vol. 36 No. 10, 2009 pp. 1008-1020

Machuki, Daniel Oenga, Challenges Facing the Implementation of Community Policing Strategy in The Urban Areas: A Case Study Of Kibra SubCounty, Nairobi, Kenya, 2012, MA Sociology Project. University Of Nairobi.

Makinda, Samuel, African Thinkers and the Global security Agenda. In Henirich Boll Stiftung (2006). Rethinking Global Security: An African Perspective,(2006) 21-39, Heinrich Boll Stiftung: Nairobi and Berlin.

McDonald, Matt, Securitization and the Construction of Security, European Journal of International Relations, (2008) 14:4

McGowan, J. Rev., A History Of China: From The Earliest Days To The Present (1897), London: Kegan Paul, Trench, Trubner and Co., Ltd.

Muhindi, Susan and Kinyanjui, Mareen, Nyumba Kumi successful despite hurdles - Kaguthi, The Star, Oct 2017. Accessed on 22 ${ }^{\text {nd }}$ August 2018, https://www.the-star.co.ke/news/2017/10/09/nyumba-kumi-successfuldespite-hurdles-kaguthi_c1648845?platform=hootsuite

Munyao, Bernard, "Nyumba Kumi clusters in some counties frustrated by security agencies, says Kaguthi," Kenya News Agency. http://kenyanewsagency.go.ke/en/?p=121168. Accessed $3^{\text {rd }}$ May 2018.

Muraya, Joseph, 200,000 clusters formed in Nyumba Kumi drive, Capital News, 2015, accessed $24^{\text {th }} \quad$ August 2018 , https://www.capitalfm.co.ke/news/2015/01/200000-clusters-formed-innyumba-kumi-drive/..

Namaye, Polly, Crime preventers link communities and police in fight against crime. Social Justice Blog., (n.d), http://www.monitor.co.ug/OpEd/Commentary/Crime-preventers-linkcommunities-and-police/689364-2843540-Un7k42z/Index.Html

Ndungu, Sarah, Nairobi resident associations to partner with county government, 2016, accessed 20 July http://www.mediamaxnetwork.co.ke/249603/nairobi-residentassociations-to-partner-with-county-government/.

Ndyabahika, David, Community Policing (Mayumba Kumi): Is this something we can trust? Social Blog, 2017, http://socialjusticeblog.kweeta.com/community-policing-is-thissomething-we-can-trust/, accessed $24^{\text {th }}$ august 2018.

Olima, Washington, Residents' Participation in Neighborhood Management and Maintenance: Experiences and Lessons from Nairobi, Kenya, (n.d), 
accessed $\quad 1^{\text {st }}$ May 2018, http://erepository.uonbi.ac.ke:8080/xmlui/bitstream/handle/11295/55149/1 65375_1.pdf; sequence=1.

Ombati, Cyrus, State tightens community policing through 'Nyumba Kumi' initiative, 2013, accessed 23rd August 2018, https://www.standardmedia.co.ke/article/2000095139/state-tightenscommunity-policing-through-nyumba-kumi-initiative.

Ouma, Joseph, Nyumba Kumi clusters successful, Kenya News agency, 2016, accessed $24^{\text {th }}$ August 2018, http://kenyanewsagency.go.ke/en/?p=81495..

Pollock, J. Daníelsson, Breaking Down the Walls of Japan Japan's Slow International Integration (2016). Accessed on $10^{\text {th }}$ May 2018. https://skemman.is/bitstream/1946/26067/1/Breaking\%20Down\%20Japan $\% 27 \mathrm{~s} \% 20$ Walls $\% 20 \% 28$ Final $\% 29 \% 20$ \%20Justin\%20\%C3\%9E\%C3\%B3r.pdf.

Republic of Kenya (a), Kenya Gazette Notice, Vol CXV-No 159, $8^{\text {th }}$ November 2013.

Republic of Kenya (b), Kiambu County Gazette Supplement, Bills 2016, Nairobi: Government Printer (2016). See also the Nairobi City County Gazette Supplement 2015.

Rwanda National Police, How Irondo has added value to safety and security in Neighborhoods. 2016, accessed $27^{\text {th }}$ January 2018, http://www.police.gov.rw/newsdetail/?tx_ttnews\%5Btt_news\%5D=8030\&cHash=6d964c46b2b5285a296 $1 \mathrm{~b} 821 \mathrm{cf5} 5 \mathrm{adabb}$.

Sabiti, Daniel, East Africa May Adopt Rwanda's Community Policing Model (2017), accessed on $27^{\text {th }}$ January 2018. http://ktpress.rw/2017/01/eastafrica-may-adopt-rwandas-community-policing-model/.

Sanchez, Yoani, Fidel's "Revolutionary Collective Surveillance Neighborhood Spies Create Social Violence and Hatred, 2012, The WorldPost accessed on 22 $2^{\text {nd }}$ December 2017. https://www.huffingtonpost.com/yoani-sanchez/fidels-revolutionarycoll_b_1921751.html

Sima, Negasa Deressa, The Role Of Rural Land Registration In Enhancing Governance And Tenure Security Of Communal Holding In Beneshangul Gumuz Regional State Of Ethiopia: Can Communal Grazing Land Be Saved From Threats Of Encroachment By The Non-Holders? The World Bank: Washington DC.

Singh, Jarmal, Crime Prevention -The Singapore Approach, Resource Material Series No. 56, (n.d) 140-150. 
Ssemakula, Shadat and Mutyab, Mohmeded, Crime Preventers A Tool For Social Cohesion In Community Policing Of Uganda, International Academic Journal Of Law And Society (Iajls) (2017) 1-24.

The World Bank, Republic of Kenya, A Country Social Profile. Washington DC: World Bank, 1-74.

Treiber, Magnus, The Kebele System in Ethiopia, n.d. accessed $18^{\text {th }}$ July 2018 , United Nations Development Program, Human Development Report, London, Oxford University Press (1994).

US Department of Justice, Neighborhood Watch Manual - USAonWatch National Neighborhood Watch Program," (2005) 1-37.

USAID Rwanda, Land Dispute Management in Rwanda Final Report. (2008a) 163.

Veltmeyer, Henry and Rushton, Mark, The Cuban Revolution as Socialist Human Development Volume 36 of Studies in Critical Social Sciences (Brill, 2011) 117-150

Vogt, L. Paul, Introduction to Rural Sociology, Appleton: New York and London. Wambui, Brenda, Nyumba Kumi and Institutional Failure in Kenya, 2016, Brainstorm Blog, accessed on 02 May 2018. http://www.brainstorm.co.ke/2013/11/12/nyumba-kumi-and-institutionalfailure-in-kenya/

Wikipedia, Human Security, Accessed on $1^{\text {st }}$ May 2018. https://en.wikipedia.org/wiki/Human_security

Xhao, Laixun, A Simple Model of the Chinese Hukou System and Some Ongoing reforms (2017), Kobe University. Accessed on 10 ${ }^{\text {th }}$ May 2018. http://www.rieb.kobe-u.ac.jp/academic/ra/dp/English/DP2016-03.pdf. 